Doi: $\underline{\text { dx.doi.org/10.17921/2525-5320.2016.286-288 }}$

\title{
ESCOLINHA DA MAÇONARIA E SEU PERCURSO HISTÓRICO NA CIDADE DE LONDRINA (1952 - 2015)
}

Fernanda Silva Camargo* - UEL

Palavras-chave: História da Educação. Instituição Escolar. Arquivo Escolar

\section{INTRODUÇÃO}

A pesquisa, desenvolvida em trabalho de conclusão de curso de Pedagogia/UEL, com o tema "Escolinha da Maçonaria e seu percurso histórico na cidade de Londrina (1952-2015)" A escolha do tema teve origem com a participação no projeto de pesquisa, realizado no Laboratório de Ensino e Pesquisa da História da Educação - LEPHE na UEL a participação no projeto de pesquisa "Localização e catalogação de fontes para pesquisa da história das instituições educativas escolares de Londrina", cuja finalidade inicial era de localizar e catalogar as fontes encontradas nas escolas estaduais da cidade, inicialmento com as 10 mais antigas da cidade. Destas, uma foi instalada por ação de um grupo religioso católico e a outra foi instalada por iniciativa de um grupo maçônico. Assim, nesta coleta, nos deparamos com a história do Colégio Estadual Dario Vellozo, uma história curiosa pelo modo como se instalou em Londrina, sendo construída e instalada pela Loja Maçônica Regeneração $3^{\circ}$ na década de 1950.

O objetivo da pesquisa ficou definido como registrar, tomando como fonte os arquivos escolares encontrados, a história do Colégio, no contexto histórico da cidade de Londrina, visando compreender seu percurso histórico e as modificações ocorridas na instituição.

\section{MATERIAL E MÉTODOS}

As fontes utilizadas foram localizadas na Loja Maçônica Regeneração $3^{a}$ que forneceu atas de reunião, que relatam o processo de constituição da Escolinha da Regeneração, além da colaboração do Colégio Estadual Dario Vellozo, que permitiu o acesso ao arquivo da escola que estava armazenada em armário no corredor,

\footnotetext{
*E-mail: fernandasilvacamargo24@gmail.com
} 
ainda sem classificação e ordenação. Assim, o primeiro passo do processo de pesquisa foi à organização desse material, separando-os primeiramente por espécie, e em ordem cronológica: Prestação de Conta; Livro Ponto; Multimídia; Documentos Históricos; Termo de Compromisso; Atas de Reuniões; Autorização e Funcionamento; Registro de Classe. Por fim selecionamos, como fontes para esta pesquisa, os Documentos Históricos e as Atas de Reuniões. Na instituição, encontramos alguns cadernos, onde eram mencionadas algumas ocasiões importantes ocorridas no Colégio Estadual Dario Vellozo, grande parte desses cadernos servia como registros de eventos feitos pelos diretores.

Todos os documentos encontrados constituem fontes importantes para a História da Educação segundo Magalhães (1999), no entanto, considerando os limites de tempo impostos para a realização da pesquisa, selecionamos Documentos Históricos e Atas de Reuniões, como fonte para esse trabalho uma vez que mostraram-se pertinentes para captar diferentes dimensões do cotidiano da instituição.

\section{RESULTADOS E DISCUSSÃO}

As atas da Loja Maçônica permitiram compreender o processo de sua instalação na cidade e as razões da abertura da "escolinha da maçonaria". Também encontramos nas atas relatos das reuniões ocorridas no Colégio Estadual Dario Vellozo, momentos em que a equipe pedagógica destacava algumas situações, como comportamento de alunos e professores, reforma do prédio escolar, preparação para alguns eventos, entre outros, com o intuito de encontrar a melhor resolução. Tais documentos permitiram compreender como foi se estruturando a vida escolar, os problemas enfrentados e as soluções encontradas. Os Documentos Históricos apresentaram momentos que foram marcantes na vida da escola, sua presença na imprensa local e uma iniciativa original, a produção de um jornal impresso pelos estudantes, com informações a respeito da vida escolar.

\section{CONCLUSÃO}

Portanto a pesquisa ocorrida no Colégio Estadual Dario Vellozo, permitiu sistematizar e relatar uma parte da história dessa instituição, sua importância no 
município de Londrina, as modificações ocorridas ao longo do tempo, conforme os documentos encontrados no colégio. Dessa maneira, percebemos importância da organização dos arquivos, por serem fontes de pesquisa tanto para a instituição quanto para o pesquisador, além de poderem representar auxilio na constituição da identidade da instituição.

\section{REFERÊNCIAS}

ABBUD, M.L.M. Localização e catalogação de fontes para pesquisa da história das instituições educativas escolares e não escolares de Londrina. In: SBHE. 2010. Anais... 2010

BAEZA, T.M.M. Manual de trabalho em arquivos escolares. São Paulo: CRE Mário Covas, IMESP, 2003.

MAGALHÃES, J. Contributo para a história das instituições educativas - entre a memória e o arquivo. In: MAGALHÃES, J. Para a história do ensino liceal em Portugal: Actas dos Colóquios do I Centenário da Reforma de Jaime Moniz (1894 1895). Braga: Secção de História da Educação da Sociedade Portuguesa de Ciência de Educação, 1999. p.63-76.

OLIVEIRA, L.H.M.M.; GATTI JUNIOR, D. História das instituições educativas: um novo olhar historiográfico. Cad. Hist. Educ., v.1, n.1, p.73-76, 2002 